\title{
Stephen Biko’s Philosophy and Its Pedagogical Implications in South Africa
}

\author{
Vuyisile Msila \\ Department of Education Leadership and Management, College of Education, University of South Africa, \\ Pretoria, South Africa \\ Email: msilavt@unisa.ac.za
}

Received May $30^{\text {th }}, 2013$; revised June $30^{\text {th }}, 2013$; accepted July $7^{\text {th }}, 2013$

Copyright (C) 2013 Vuyisile Msila. This is an open access article distributed under the Creative Commons Attribution License, which permits unrestricted use, distribution, and reproduction in any medium, provided the original work is properly cited.

\begin{abstract}
There are many approaches that need to inform education systems around the world. It also matters to know whether policymakers have followed (for example), a socialist or an individualist approach in formulating an education system. Furthermore, teachers and other role-players need to understand the paradigm that undergirds their system of education. This article focuses on the ideas of Stephen Biko, a South African political activist whose ideas proliferated in the 1970s. The article shows that certain values are crucial in building education founded on sound social justice policies. Most importantly, it displays that education is never a neutral act and that it will always be influenced by political debates and philosophies in a country.
\end{abstract}

Keywords: Fundamental Pedagogics; Liberatory Education; Political Ideals; Social Justice; Values

\section{Introduction}

Bantu Stephen Biko became known around the world after his death at the hands of the apartheid police in 1977 . He was the Black Consciousness (BC) leader who stood for human rights of the oppressed Black people in South Africa. The BC that Biko stood for was defined as "an inward-looking process to infuse people with pride and dignity” (Wilson, 2012: p. 14). There are critics who argue that among others, Biko was inspired by the Black Power movement in America as well as philosophers such as Frantz Fanon and Paulo Freire. Carmichael and Hamilton (1967) defined the role of the Black Power movement as a means of encouraging a new consciousness among Black people which would make it possible for them to proceed in the struggle for human rights. Wilson (2012: p. 14) also postulates as she writes about Biko:

Young as he was, he realized that a new psychological climate had to be created if the liberation of his country was to come about. He expressed what he saw as bitter the truth. Of prime importance was "to awaken the people as to who they are by getting them to state their identity. He thought that if you could do that, then there was no stopping them from revolution,” explained his colleague Malusi Mpumlwana.

Biko's philosophy emphasized a number of aspects as highlighted above. Among these were African humanism, affirmation of Black identity; the psychological emancipation. His philosophy underscored the idea of Black people living in apartheid South Africa to be able to free themselves from physical and mental bondage. This article explores the implications of Biko's philosophy in education. Although Stephen Biko died in 1977 after being tortured by apartheid police, his ideas lived long after him. Arguably, some critics still maintain that they are still relevant in today's post-apartheid South Africa. Using the findings I gathered from an earlier study (Msila, 2012) on his biographical movie, Cry Freedom, in this article I specifically look at the pedagogical implications of his philosophy. I do this by firstly exploring the ideas of Fanon and the Black Power movement; exploring how these might have inspired Biko. Then the article focuses on three aspects and how they can be informed by Biko's philosophy. These three are African humanism; identity and culture as well as education and languages.

\section{Objectives of the Study}

This article, as it explores the pedagogical implications of Biko's philosophy also seeks to:

- explore existing research on Biko's philosophy and its implications on education;

- examine how this philosophy is linked to other similar philosophies; and

- investigate the extent in which politics can affect or impact on education.

\section{Theory: Fanon and Black Power}

Gibson (2011, p. 1) points out that, "Perhaps the most important recreation of Fanon's philosophy of liberation on the African continent was by Steve Biko, whose emphasis on the liberation of the 'mind' of the oppressed became essential to the new stage of revolt against apartheid in the 1970s". Fanon talked about the importance of freeing the mind of the colonized. He stressed the importance of the African mind to shed itself of colonial domination. Fanon was a revolutionary writer 
who espoused the conditions of the oppressed. These people, "the damned of the earth" need to constantly fight exploitation and hunger as people try to change their lives (Fanon, 1967).

In his book, Black Skins, White Masks (1967) Fanon explicates the sense of dependency, helplessness and inadequacy that Black Africans experience in a "White world". Fanon, a qualified psychiatrist, uses psychoanalysis to explain the Black behavior after the loss of culture. Amongst others, Fanon raises an argument that it is because of language that people in former colonized states experience marginalization, pathologization and servitude. He says that language is an index of power imbalance and cultural difference. Furthermore, Fanon (2001) states that colonialism not only physically disarms the colonized subject, but it also rob her of a pre-colonial cultural heritage. Language, like culture negatively transformed the colonized to assume an identity of being The Other. As traditional culture dissipated among the indigenes, the creation of otherness seeped through. Black Africans became poorer and poorer and regarded the colonizer as the provider. There developed a schism between the Black African and the Westerner:

The creation of otherness (also called othering) consists of applying a principle that allows individuals to be classified into two hierarchical groups: them and us. The outgroup is only coherent as a group as a result of its opposition to the in-group and its lack of identity. This lack is based on stereotypes that are largely stigmatizing and obviously simplistic. The in-group constructs one or more others, setting itself apart and giving itself an identity (Staszak, 2008: p. 2).

The politics of colonialism and racism further entrenched this otherness. The Black African was marginalized by the dominant White society.

Similar to this philosophy is the philosophy of the Black Power movement. In fact, Joseph (2003) refers to Fanon as a man who was viewed as a future icon of the Black Power movement in its early stages. The Black Power movement in America espoused the politics of liberation of the Black people. Like Fanon above, Carmichael and Hamilton (1967) postulate that Black people needed to redefine themselves. These authors also point out that the fundamental need for Black people was to reclaim their history and identity from what they referred to as cultural terrorism. Furthermore, Carmichael and Hamilton (1967: p. 44) aver:

The concept of Black Power speaks to all the needs mentioned in this chapter. It is a call for Black people in this country to unite, to recognize their heritage, to build a sense of community. It is a call for Black people to begin to define their own goals, to lead their own organizations and to support these organizations. It is a call to reject the racist institutions and values of this society.

The above clearly illustrates the envisaged propinquity between Black Power movement and Fanon's philosophy. Both philosophies support the call for the oppressed to fight for their rights. The goal of both is the liberation of the marginalized and oppressed people. The Black Power movement emphasized racial pride and political self-determination (Joseph, 2009). Furthermore, Joseph argues that it called for a redefined Black identity that connected Black Americans to a national and global political project based on solidarity and a shared history of racial oppression. "The Black Power movement, in its chal- lenge of postwar racial liberalism, fundamentally transformed struggles for racial justice through an uncompromising quest for social, political, cultural, and economic transformation” (Joseph, 2009: p. 753). Black Power expressed a concept that negated racial oppression and it advanced a self-sufficient economy.

The Black Power movement also instilled a sense of pride among the oppressed. Children were taught to love their blackness (Van DeBurg, 1992). Later the Black Power movement produced cultural products that imbued pride in blackness. Thus it used all available forms of folk, literary and dramatic expression based in a common ancestral past to promote a message of self-actualization and cultural definition (Van DeBurg, 1992). Biko shared the ideals of these schools of thought that came before him. The emancipation of the oppressed Black people in South Africa was dependent upon the oppressed fighting for their liberation. Biko asserted that Black people are the only ones who could liberate themselves from political oppression (Wilson, 2012).

\section{Education: The Context in Which Biko Wrote}

Biko's philosophy needs to be understood within the context in which it was written. When he formulated his ideas on education and various other political and societal challenges there were a number of education systems in South Africa for different racial groups. All these were guided by the apartheid philosophy of Fundamental Pedagogics which in turn was based on what was referred to by the White Afrikaner church as Christian National Education (CNE). This was a philosophy that purported to be propelled by Calvinism and Christian Nationalism. Fundamental Pedagogics also regarded all children as blank slates or tabula rasas. Du Plooy and Kilian (1983) point out that man (sic) is educating his children with a view to assisting them educatively "to become proper human beings on their way to adulthood”. Education under Fundamental Pedagogics envisaged the role of the adult to be that an imparter of knowledge upon the child. "There is only one way in which to realize the child's becoming an adult and that is with the help and accompaniment of a responsible adult as his fellow man” (Du Plooy \& Kilian, 1983: p. 4).

Within this rather twisted view of education apartheid education regarded Bantu Education for Blacks as a form of domination over the oppressed. Article 15 of the CNE document declared:

We believe that the calling and task of White South Africa with regard to the native is to Christianise him and help him on culturally, and that this calling and task has already found its nearer focusing in the principles of trusteeship, no equality and segregation. We believe besides that any system of teaching and education of natives must be based on the same principle. In accordance with these principles we believe that the teaching and education of the native must be grounded in the life and worldview of the Whites most especially those of the Boer nation as senior White trustee of the native...

Apartheid education system abused religion while it enforced divisions among ethnic groups in South Africa. It was a practice of maintaining that status quo and of preserving the masterservant relationship between the Black Africans and the Whites. It was intended to "entrench apartheid capitalism", as was noted 
at the conference on People's Education in December 1985. Kallaway (1988) points out that apartheid education not only domesticated the people but indoctrinated them as well. Bantu Education for Black South Africans had been a means of restricting the development of the learner by distorting school knowledge to ensure control over the intellect of the learners and teachers, and propagating state propaganda (Kallaway, 1988).

The CNE principles on education for the Africans were declared as a way of maintaining the Black South Africans in a permanent state of political and economic subordination. The education system had been an obvious instrument of control to protect power and privilege. And not only had apartheid education separated White children from Black children; it had also divided White children into separate camps (Hartshorne, 1986). The Black learners did not only feel the damaging effects of the CNE. It was destructive to the White learner as well because they learnt only a White view of society. Several government reports spelt out the objectives of apartheid clearly.

The Eiselen Report was based on the Eiselen Commission which was operational in the 1950s when the Bantu Education system for Black Africans was introduced in South Africa. The Commission claimed that Black African children's intellect was of a different nature to that of Whites, and that these learners thus needed a special sort of education. Furthermore, the Eiselen Report also pointed out that Black Africans should not imitate English and other European cultures; they should stick to education that inculcates the character of a unique (African) people (Giliomee, 2009: p. 194). Bantu Education was based on this premise. The teacher unions during this period were opposed to this system which emphasized racial difference and white superiority. Arguably, the specter of apartheid education still looms large. Many teachers were trained under this system. Stephen Biko wrote many of his essays responding to this system. Below, the focus is on how Biko's philosophy responds to educational challenges today. It does this by teasing the various themes that Biko underscored in his writings on society and education.

\section{Biko and Black Consciousness}

Having unpacked Fanon and the Black power movement's beliefs, it is also crucial to briefly demonstrate what Biko's BC stood for. This is crucial in understanding how he perceived the role of education in society. Biko had read Paulo Freire's Pedagogy of the Oppressed and later concurred that teaching should be a political act, "directly related to production, health, social conditions, to the regular system of instruction, and to the overall plan for a society still to be realized in the future" (Wilson, 2012: p. 59). In his own words Biko states that, "Black Consciousness therefore, takes cognizance of the deliberateness of God's plan in creating black people black. It seeks to infuse the black community with a new-found pride in themselves, their efforts, their value systems, their culture, their religion and their outlook to life” (Biko, 1987: p. 49). He always perceived an intense interrelationship between the consciousness of self and emancipatory agenda. Therefore, Biko defined Black Consciousness as an attitude of the mind and a way of life. Its philosophy was to express "group pride and a determination of the Black people to arise and attain the envisaged self” (Wilson, 2012).

\section{Identity and Culture}

The Black Consciousness that Biko stood for accentuated the affirmation of Black culture and Black identity. Biko was against racial integration, which emphasized an assimilationist position. He did not approve of the disadvantaged people having to accept a set of norms and code of behavior set up and maintained by Western values. For Biko (1987: p. 24), true integration meant:

Free participation by all members of a society, catering the full expression of the self in a freely changing society as determined by the will of the people... For one cannot escape the fact that the culture shared by the majority group in any given society must ultimately determine the broad direction taken by the joint culture of that society. This need not cramp the style of those who feel differently buit on the whole, a country in Africa, in which the majority of people are African must inevitably exhibit African values and be truly African in style.

He also goes on to bewail the destruction of structures built in the African society by colonialism and imperialism. He contends that not only was the Native's brain emptied but the history was deliberately distorted as well. As history was destroyed, so was the culture:

No longer was reference made to African culture, it became barbarism... Religious practices and customs were referred to as superstition... No wonder the African child learns to hate his heritage in his days at school. So negative is the image presented to him that he tends to find solace only in close identification with the white society (Biko, 1987: p. 29).

The participants reiterated the commitment Biko showed towards culture and identity in the movie. They perceived him as a man who saw culture and identity as conduits to pride and affirmation of being a rightful citizen in South Africa. The participants also saw Biko as magnifying the role of being "true African”. However, Biko did not believe that African culture is static. Many skeptics of Africanization usually pose questions such as; what is culture? Whose culture?-In a very tongue in cheek manner. It is true that as people enhance their nation building endeavors they need to explain what they mean by culture. Biko was appalled at the fact that Africans were not expected to have any understanding of their own cultures. He maintained that people needed to relate the past to the present and demonstrate an historical evolution of the modern African. Biko (1987: p. 70) contends:

We must reject the attempts by the powers that be to project an arrested image of our culture... They have deliberately arrested our culture at the tribal stage to perpetuate the myth that African people were near cannibals, had no real ambitions in life, and were occupied with sex and drink.

African cultures as envisaged in the Africanization process need to be seen in light of this dynamism. It is also crucial that people must not delude themselves by thinking that there is one African culture in Africa or South Africa. Within Africa, there are myriad cultures as there are languages and religions. However, culture here would refer to the basic inspiration and ethos of belonging to Africa. It is that which connects the band of 
Africans together including history and commitment of being born in the Continent.

Dei (2012) argues that there is a need to reclaim local cultural resource knowledge that herald issues of the past, culture, ancestral knowledge, history, heritage and language. Furthermore Dei underscores the re-assertion of identities that recognize the genuineness of African voice and human experience. Dei (2012: p. 47) avers:

Reclaiming and affirming African past intellectual traditions, knowledge and contributions in world history is a necessary exercise in our own decolonization. African peoples have something to offer to the world. Besides our humanism we have a gift of knowledge that helps to inform an understanding of humanity. Reflecting on the African past, present and future as a continuum offers important lessons for Africans to design own futures.

These arguments support the identity and culture that Biko talks about. The Black Power movement and Fanon cited in literature above also concur with this reclaiming of the rightful culture and identity. The qualities highlighted above are all crucial in empowering the African people. Biko (1987) argued that the African child in school learns to hate his heritage because at school the African image is presented so negatively that the Black child tends to identify with the white society. Furthermore, Dei (2012) opines that there needs to be a redefined decolonized education to build spiritually and politically sustainable communities of learning. He then refer to the latter as schooling as community. In this way education according to Dei translates into pedagogy of hope that empowers the learners.

Dei also points out that African people need education where the African learners are at the center. He also points out that such education should emphasize the centrality of culture to pedagogy as it affirms identity. "African-centered education works with principles of community, solidarity, social responsibility, mutual independence, collective histories and spiritual learning” (Dei, 2012: p. 51). Biko (1987) cites Fanon when he emphasizes the need for a national consciousness. He says colonialism has destroyed the essence of Black people. As a result, "at the end of it all, the Blacks have nothing to lean on, nothing to cheer them up at the present moment and very much afraid of in the future" (Biko, 1987: p. 69). There is a special place of a teacher who enhances the learners' selves, collective ethnic and cultural pride for a strong African identity and personality. Biko maintained that these are all qualities that need to be emphasized in African classrooms in order for the learners to regain self-worth and confidence in the world. This culture and identity is linked to ubuntu or African humanism that Biko espoused.

\section{African Humanism: Building Ubuntu}

Biko's BC was a perpetual quest for humanism. In South African Nguni languages this is what is referred to as ubuntu. Ubuntu is the actual meaning of life in African societies. One lives for fellow brethren; a neighbor cannot starve if I have victuals however, small. The latter is an inherent African value and Biko (1987: p. 24) argued that, "In Africa, in which the majority of the people are African must inevitably exhibit African values and be truly African in style”. Furthermore, Biko contends that Africans develop a sense of belonging to the community within a short time of coming together. He says that the oneness of community is at the heart of the Black African cultures and the easiness in which the Africans communicate with each other is not forced by any authority but is inherent in the genes of the African people. The BC philosophy wanted the Black people to value their own lifestyle, their outlook and standards.

Boaduo (2012) extends Biko's arguments in her discussions. She contends that there is a need for South African education to play a role of humanizing its citizens on principles based on ubuntu. She also speaks of a need to re-educate the ethnic groups that were injured by apartheid policies. This author states that the dehumanization of South Africans affected all racial groups. The White South Africans in the process of indoctrinating their children dehumanized their ethnic group. "In the same way the Black racial groups who have been deliberately de-humanized and excluded from any worthwhile participation in government including their various counterparts-Indians and Coloreds also need to be re-educated” (Boaduo, 2012: p. 955).

Mthembu (1996) describes ubuntu as the key to all African values and that it involves humanness, a good disposition towards others, and a moral nature. Furthermore, Mthembu avers that ubuntu describes the significance of group solidarity and interdependence in African culture. Mbigi (2005: p. v) supports this by pointing out that ubuntu is a metaphor that describes the significance of group solidarity on survival issues that is so vital to the survival of African communities. Schools tend to reflect the society in which they are built. Parts of ubuntu are manifested through certain aspects such as humanism that Biko also explored. There are however, many challenges to ubuntu way of life in the present society. If Biko were alive he would disappointed by the levels of societal ills such as xenophobia, crimes, declining morality among Black Africans. In fact, Ntuli (1999: p. 184) states that the spirit of ubuntu has long disappeared and he states that that is the reason why we need an African renaissance. Furthermore, Ntuli opines that in the face of the present cultural and moral collapse in South Africa, there is a need to strive for a rebirth. Yet, Dandala (1996: p. 70) states that ubuntu requires a great deal of learning and sharing and institutions can achieve this through the training of people to practice greater interaction. Schools and the societies around them need to learn the values of ubuntu.

\section{Education and Languages}

Biko (in Woods) maintained that there was a need for Black people to use indigenous languages because they could express themselves better in their mother tongue. He pointed out that speaking another language makes many students to feel "a sense of inadequacy”. Biko also stated that when students cannot express themselves in a foreign language they tend to judge themselves negatively. They tend to contend that their intelligence is not as good as that of first language speakers of English for example. "You tend to feel that that guy is better equipped than you mentally” (Woods, 1991: p. 169). The idea of using indigenous languages in schools has never been so relevant in the education discourse. Many critics cite the non-use of indigenous languages in schools as among the crucial reasons as to why Black learners do not fare well in their studies in South Africa. Furthermore, Biko declared that this difficulty of coping with a foreign language in schools led to an inferiority com- 
plex. Language created Blacks who had an inferiority complex. Biko also writes about how Black people became less articulate, inward looking because of the lack of linguistic skills. In a foreign language, "you feel things rather than say them... English is completely foreign and therefore people find it difficult to move beyond a certain point in their comprehension of the language” (Biko, 1987: p. 123).

Like Biko, Fanon argued more about language implications. He points out that being colonized by a language has deep implications for one's consciousness. Fanon (1967) also contended that the use of foreign languages by Black people alienated the people from their natural selves creating a disjuncture between the Black man's consciousness and his body. Furthermore, he identifies the use of language as a tool for liberation for the colonized (1967). Clearly, Biko and Fanon perceived language as an aspect of culture and identity that should not be destroyed. The Black Power movement also emphasized that for Black people to understand themselves, they should not be alienated from their culture and identity (McCormack, 1984).

\section{Conclusion}

Arguably, the ideals of democracy, equality and social justice should be pivotal in teacher education programs. Without these aspects post-apartheid education will not achieve what it is supposed to achieve. The South African education is built upon the democratic constitution of the Republic. Values embraced by philosophers such as Biko will be crucial in realizing some of the ideals of the post-apartheid education system. Biko used liberation theories to emancipate the individuals from the constraints enforced by society. Existing research on Biko also shows the implications of Biko's philosophy on the society in general. This article has also revealed how his theory shares similar notions to Frantz Fanon's as well as the Black Power movements. There are others that are relevant such as Paulo Freire's pedagogy which is not discussed in this article. The article has also illustrated how political debates cannot be separated from pedagogic arguments. Education is intertwined with society and although Biko was mainly commenting on society and politics, his philosophy has huge implications for education. Finally, through Biko's philosophy one can see that education is always based on values and it is through values that individuals will find liberating or restricting.

\section{REFERENCES}

Biko, S. (1987). I write what I like. Oxford: Heinemann.

Boaduo, N. A. (2012). Philosophical analysis of education for the enhancement of development, social justice and good governance in
South Africa. Educational Research, 3, 954-960.

Carmichael, S., \& Hamilton, C. V. (1967). Black power: The politics of liberation in America. New York: Vintage Books.

Dandala, H. M. (1996). Cows never die: Embracing African cosmology in the process of economic growth. In R. Lessem, \& B Nassbaum (Eds.), Sawubona Africa: Embracing four worlds in South African management (pp. 69-85). Sandton: Zebra.

Dei, G. J. S. (2012). Reclaiming our Africanness in the disporised context: The challenge of asserting a critical African personality. The Journal of Pan African Studies, 4, 42-57.

Du Plooy, J. L., \& Kilian, C. J. G. (1983). Introduction to fundamental pedagogics. Pretoria: Haum Educational Publishers.

Fanon, F. (1967). Black skins, white masks (Translated by C. L. Markmann). New York: Grove Press.

Fanon, F. (2001). The wretched of the earth (translated by C. Farrington). New York: Grove Press.

Gibson, N. C. (2011). Fanonian Practices in South Africa: From steve biko to abahlali basemjondolo. Scottsville: University of KwaZuluNatal Press.

Giliomee, H. (2009). A note on bantu education, 1953 to 1970. South African Journal of Economics, 77, 190-198. doi:10.1111/j.1813-6982.2009.01193.x

Hartshorne, K. B. (1986). INSET in South Africa: HSRC report 1985. Bloemfontein: The Urban Foundation.

Joseph, P. E. (2003). Dashikis and democracy: Black studies, student activism, and the black power movement. The History of Black Student Activism, 88, 182-203.

Joseph, P. E. (2009). The black power movement: A state of the field. The Journal of American History, 751-776. doi:10.1093/jahist/96.3.751

Kallaway, P. (1988). From Bantu education to peoples' education. Cape Town: UCT.

Mbigi, L. (2005). Ubuntu: The spirit of African transformation management. Randburg: Knowledge Resources.

McCormack, D. J. (1984). Black power: Political ideology. Ann Arbor: University of New York.

Msila, V. (2012). Memory, educators and pedagogy: Viewing cry freedom-unearthing Biko's philosophy in the classroom. Journal of Sociology and Anthropology, 3, 163-171.

Mthembu, D. (1996). African values: Discovering the indigenous roots of management. In R. Lessem, \& B. Nassbaum (Eds.), Sawubona Africa: Embracing four worlds in South African management (pp. 215226). Sandton: Zebra.

Ntuli, P. (1999). The missing link between culture and education: Are we still chasing Gods that are not our own? In M. W. Makgoba (Ed.), African renaissance (pp. 184-199). Cape Town: Mafube.

Staszak, J. (2008). Publie dans international encyclopedia of human geography. Amsterdam: Elsevier.

Van DeBurg, W. L. (1992). New day in Babylon: The black power movement and American culture, 1965-1975. Chicago: University of Chicago Press.

Wilson, L. (2012). Steve Biko. Auckland Park: Jacana.

Woods, D. (1991). The true story of the young South African martyr and his struggle to raise Black Consciousness. New York: Henry Holt and Co. 